\title{
Bay Fruit Oil
}

National Cancer Institute

\section{Source}

National Cancer Institute. Bay Fruit Oil. NCI Thesaurus. Code C107270.

The oil extracted from the fruit of Laurus nobilis. Bay fruit oil can be used for its antirheumatism effects. 